\title{
PEMBERIAN JUS BUAH NAGA MEMPENGARUHI KADAR HEMOGLOBIN PADA IBU HAMIL
}

\author{
Nani Soleha ${ }^{1}$, Astriana $^{2}$, Khoidar Amirus ${ }^{3}$ \\ 1Program Studi DIV Kebidanan Fakultas kedokteran Universitas Malahayati \\ email: nanisoleha24@gmail.com \\ 2Program Studi DIV Kebidanan Fakultas kedokteran Universitas Malahayati \\ email: ashtry_hs@yahoo.co.id \\ ${ }^{3}$ Dosen Fakultas Kesehatan MasyarakatUniversitas Malahayati
}

\begin{abstract}
Background :Hemoglobin levels are biochemical indicators to determine the nutritional status of pregnant women. Normal pregnancy decreases slightly in hemoglobin concentration due to hypervolemia which occurs as a physiological adaptation in pregnancy. Red blood cells that function to deliver oxygen throughout the body, if $\mathrm{Hb}$ is reduced, the body's tissues lack oxygen. Preliminary survey conducted by researchers in January 2019 from the results of observations at the West Lampung Liwa Public Health Center in the ANC book found 147 pregnant women, namely TM 1 (49 people), TM II (53 people) and TM III (45 people).

The purpose of this research is to know the effect of giving dragon fruit juice on hemoglobin levels in pregnant women..

Methode :This research method is a pre-experimental action research with One group pretest - posttest design. The population was all pregnant mothers who were anemic in the Liwa Health Center as many as 34 mothers. A sample of 18 people, the sampling technique used was purposive sampling. Data collection using observation sheets and data analysis used is the T-dependent test.

Result :The results of the study revealed the average value of hemoglobin levels before administration of 9,761 dragon fruit juice and standard deviation of 0.5304. The average value of hemoglobin levels on the 15th day of giving dragon fruit juice is 11,583 and the standard deviation is 0.6888 .

Conclusion: There Is An Effect Of Giving Dragon Fruit Juice On Increasing Hb Levels In Pregnant Women (p value $0,000<0.05$ ).

Suggestions as a non-pharmacological method for the action of raising hemoglobin levels one of which is by giving dragon fruit juice on increasing levels of $\mathrm{Hb}$ in pregnant women and conducting counseling to increase pregnancy knowledge about handling anemia.
\end{abstract}

Keywords: pregnant women, anemia, dragon fruit juice, hemoglobin levels

\section{ABSTRAK}

Latar Belakang : Kadar hemoglobin merupakan indikator biokimia untuk mengetahui status gizi ibu hamil. Kehamilan normal terjadi penurunan sedikit konsentrasi hemoglobin dikarenakan hipervolemia yang terjadi sebagai suatu adaptasi fisiologis di dalam kehamilan. Sel darah merah yang berfungsi menyalurkan oksigen ke seluruh tubuh, jika $\mathrm{Hb}$ berkurang, jaringan tubuh kekurangan oksigen. Survey pendahuluan yang peneliti lakukan pada januari Tahun 2019 dari hasil observasi di Puskesmas Liwa Lampung Barat pada buku ANC diketahui 147 ibu hamil yaitu TM 1 (49 orang), TM II (53 orang) dan TM III (45 orang).

Tujuan penelitian adalah diketahui pengaruh Pemberian Jus Buah naga Terhadap Kadar Hemoglobin Pada Ibu Hamil.

Metode : Metode penelitian ini merupakan penelitian tindakan pra eksperimen dengan rancangan One group pretest - posttest design. Populasi adalah Seluruh ibu hamil yang anemia di Puskesmas Liwa Sebanyak 34 ibu. Sampel 18 orang, Teknik sampling yang digunakan purposive sampling. Pengumpulan data dengan menggunakan lembar observasi dan analisa data yang digunakan adalah uji T-dependent.

Hasil : Hasil penelitian diketahui Nilai rata-rata kadar hemoglobin sebelum pemberian Jus buah naga 9.761 dan standar deviasi 0.5304 . Nilai rata-rata kadar hemoglobin pada hari ke 15 pemberian Jus buah naga 11.583 dan standar deviasi 0.6888 .

Kesimpulan : Ada Pengaruh Pemberian Jus buah naga Terhadap Peningkatan Kadar Hb Pada Ibu Hamil ( $p$ value $0,000<0,05$ ). 
Saran sebagai metode nonfarmakologi untuk tindakan menaikkan kadar hemoglobin salah satunya dengan Pemberian jus buah naga terhadap peningkatan kadar Hemoglobin pada ibu hamil serta melakukan penyuluhan-penyuluhan untuk menambah pengetahuan hamil tentang penanganan anemia.

Kata Kunci : ibu hamil, anemia, jus buah naga, kadar hemoglobin

\section{PENDAHULUAN}

Hemoglobin memiliki peran penting dalam mengantar oksigen keseluruh bagian tubuh untuk konsumsi dan membawa kembali karbon dioksida kembali ke paru menghembuskan nafas keluar dari tubuh. Jika kadar hemoglobin terlalu rendah. Proses tingkat oksigen yang rendah (hipoksia). Anemia umumnya memiliki prognosis yang sangat baik dan mungkin dapat disembuhkan dalam banyak hal. Prognosis keseluruhan tergantung pada penyebab anemia, tingkat keparahan, dan kesehatan keseluruhan pasien. Anemia yang parah dapat menyebabkan rendahnya kadar oksigen pada organ-organ vital seperti jantung, dan dapat menyebabkan serangan jantung. (Proverawati, 2011).

Anemia adalah sebuah kondisi dimana kadar hemoglobin seseorang kurang dari $11 \mathrm{~g} / \mathrm{dl}$ pada trimester pertama dan ke tiga, dan kurang dari 10,5 g/dl pada trimester kedua. Hemoglobin merupakan zat warna yang terdapat dalam sel darah merah dan berguna untuk mengangkut oksigen dan karbon dioksida dalam tubuh, hemoglobin adalah ikatan protein, garam besi, zat warna. Sebagian besar ibu hamil akan mengalami beberapa tingkat anemia karena zat besi di butuhkan untuk menghasilkan sel darah merah pada janin. Anemia bisa muncul selama kehamilan karena kekurangan asam folat. Saat kehamilan, anemia dapat di cegah dan di obati dengan menggunakan zat besi dan suplemen asam folat. (Winarsih, 2018 ).

Sekitar 95\% kasus anemia selama kehamilan adalah karena kekurangan zat besi (anemia defisiensi besi). Penyebabnya biasanya asupan makanan tidak memadai (terautama pada anak perempuan remaja), kehamilan sebelumnya, atau kehilangan normal secara berulang zat besi dalam darah haid (yang mendekati jumlah tertentu, biasanya berlangsung setiap bulan dan dengan demikian mencegah penyimpanan zat besi). (Proverawati, 2011).

Jika anemia menjadi parah dan berlangsung lama, maka jumlah darah untuk membawa oksigen menurun, akibatnya, janin tidak bisa mendapatkan cukup oksigen yang di butuhkan untuk pertumbuhan normal,kususnya pada otak. Ibu hamil yang mengalami anemia berat akan timbul gejala seperti rasa lelah yang berlebihan, nafas tersengal- sengal, nyeri kepala, dan mata berkunang-kunang. Risiko preterm meningkat saat persalinan. Dalam masyarakat yang pola makan sehari-hari sebagaian besar dari sumber nabati, adanya penyakit infeksi maupun investasi parasit sangat berperan terhadap anemia besi. Rendahnya kadar zat besi yang terkandung dalam sumber nabati hanya merupakan sebagaian dari alasan tingginya angka prevalensi anemia gizi di indonesia (Winarsih, 2018)

Perawatan anemia sangat bervariasi dan tergantung pada penyebab dan beratnya anemia. Jika anemia ringan dan berhubungan dengan tanpa gejala atau gejala minimal, penyelidikan menyeluruh oleh dokter akan dilakukan di luar pasien. Jika penyebab telah ditemukan, maka perawatan yang tepat akan dimulai (Proverawati, 2018).

Menurut WHO (2008), prevalensi anemia pada ibu hamil diperkirakan di Asia sebesar 48,2\%, Afrika 57,1\%, Amerika 24,1\%, dan Eropa 25,1\%. Berdasarkan riskesdas 2013 terdapat 37,1\% ibu hamil anemia, yaitu ibu hamil dengan kadar $\mathrm{Hb}$ kurang dari 11,0 gram/dl, dengan proporsi yang hampir sama antara di kawasan perkotaan $(36,4 \%)$ dan pedesaan $(37,8 \%)$ (Riskesdas, 2013). Meskipun pemerintah sudah melakukan program penanggulangan anemia pada ibu hamil yaitu dengan memberikan 90 tablet Fe kepada ibu hamil selama periode kehamilan dengan tujuan menurunkan angka anemia ibu hamil, tetapi kejadian anemia masih tinggi. (Kementerian Kesehatan RI, 2013).

Berdasarkan data WHO 2015, anemia merupakan salah satu faktor penyebab tidak langsung kematian ibu hamil. Berdasarkan WHO prevalensi anemia ibu hamil di dunia berkisar ratarata $14 \%$, dinegara industri $56 \%$ dan di negara berkembang antara $35 \%-75 \%$. Secara global, sebesar $52 \%$ wanita hamil di negara-negara berkembang mengalami anemia. Angka ini lebih besar di bandingkan dengan angka anemia pada wanita hamil di negara-negara industri yang hanya sebesar 20\%. Negara dengan prevalensi anemia pada wanita hamil tertinggi adalah india ( $88 \%$ ), di ikuti oleh afrika (50\%), dan karibia $(30 \%)$. Berdasarkan WHO tahun 2008 prevalensi anemia ibu hamil di asia tenggara $48,2 \%$. Menurut encyclopedis of national indonesia berada di 
peringkat ke-58 dengan prevalensi anemia pada ibu hamil sebanyak 44,3\%. (istiyati, 2019).

Berdasarkan data Riskesdas 2018, angka anemia ibu hamil sebanyak 48,9\%, anemia berdasarkan umur 15-24 tahun sebanyak $84,6 \%$, 25-34 tahun sebanyak 33,7\%, 35-44 tahun sebanyak $33,6 \%$ dan umur $45-55$ tahun sebanyak $24 \%$. Sedangkan ibu hamil yang mendapat tablet tambah darah sebesar $73,2 \%$ dan yang tidak mendapatkan tablet tambah darah sebesar 26,8\% (Riskesdas, 2018).

Berdasarkan profil kesehatan provinsi Lampung tahun 2017 menunjukan data bahwa dari 24733 ibu hamil yang terdapat di Provinsi Lampung sebanyak 21771 (88\%). Ibu hamil yang mengalami anemia berjumlah $8435(36,4 \%)$ dengan kadar $\mathrm{Hb}$ 8-11 gr/dl dan 810 ibu hamil atau (3,4\%) dengan kadar $\mathrm{Hb}<8 \mathrm{gr} / \mathrm{dl}$. (Profil Kesehatan Provinsi Lampung, 2017).

Berdasarkan data dinas kesehatan kabupaten lampung barat, 2018 data anemia ibu hamil di Lampung Barat pada tahun 2017 terdapat 213 orang ibu hamil dengan anemia dan mengalami peningkatan pada tahun 2018 sebesar 235 orang ibu hamil dengan anemia (Dinas Kesehatan Kabupaten Lampung Barat, 2018).

Survey pendahuluan yang peneliti lakukan pada januari Tahun 2019 dari hasil observasi di Puskesmas Liwa Lampung Barat pada buku ANC diketahui 147 ibu hamil yaitu TM 1 (49 orang), TM II (53 orang) dan TM III (45 orang). Alasan peneliti mengambil penelitian tentang buah naga karena zat besi dan vitamin $C$ yang berperan penting dalam manfaat untuk ibu hamil. Dengan mengonsumsi buah naga secara teratur, kadar hemoglobin dapat meningkat sehingga ibu hamil takkan mengalami kekurangan darah atau anemia. Zat besi sebagai bahan baku sel darah merah, sedangkan vitamin $\mathrm{C}$ sebagai membantu mengoptimalkan penyerapan zat besi melalui saluran cerna. Selain itu, di puskesmas Liwa, karena ibu hamil disana belum banyak mengetahui manfaat jus buah naga serta belum pernah dilakukan observasi penyuluhan untuk meningkatkan kadar hb pada ibu hamil, sehingga peneliti tertarik untuk melakukan penelitian tentang "Pengaruh Pemberian Jus Buah Naga Terhadap Kadar Hemoglobin Pada Ibu Hamil Di Puskesmas Liwa Lampung Barat Tahun 2019"

\section{METODOLOGI PENELITIAN}

Jenis penelitian yang digunakan dalam penelitian ini adalah kuantitatif dengan pendekatan quasi eksperimen dengan rancangan One group pretest - posttest design. Tempat penelitian ini dilaksanakan di Puskesmas Liwa Lampung Barat.
Waktu penelitian telah dilaksanakan pada bulan Januari - Juli 2019.

Populasi dalam penelitian ini adalah Seluruh ibu hamil yang anemia di Puskesmas Liwa Sebanyak 34 ibu pada bulan januari- Maret 2019 dengan jumlah sampel dalam penelitian ini sebanyak 18 orang, dengan teknik sampling menggunakan purposive sampling yaitu mengambil sampel berdasarkan kriteria yang peneliti tentukan(Notoatmodjo, 2018).

HASIL PENELITIAN

Analisis univariat

Kadar Hemoglobin Sebelum Pemberian Jus buah naga

Tabel 1.

Distribusi frekuensi rata-rata kadar $\mathrm{Hb}$ sebelum pemberian Jus buah naga Pada Ibu Hamil Di Puskesmas Liwa Lampung Barat Tahun 2019

\begin{tabular}{lcccc}
\hline \multicolumn{1}{|l}{ Variabel } & $\mathrm{N}$ & Mean & Min-Mak & $\mathrm{SD}$ \\
\hline $\begin{array}{l}\text { Sebelum } \\
\text { pemberian } \\
\begin{array}{l}\text { Jus buah } \\
\text { naga }\end{array}\end{array}$ & 18 & 9.761 & $9,0-10,5$ & 0.5304 \\
\hline
\end{tabular}

Berdasarkan tabel. 1 Hasil analisis dapat dilihat dari 18 responden, diketahui bahwa pemberian Jus buah naga terhadap kenaikan kadar hemoglobin pada ibu hamil nilai minimal (nilai kadar hemoglobin terendah) 9.0 dan nilai maksimal (nilai kadar hemoglobin tertinggi) 10,5 dengan nilai ratarata sebelum pemberian Jus buah naga 9.761 dan standar deviasi 0.5304 .

Tabel 2.

\section{Distribusi frekuensi rata-rata kadar $\mathrm{Hb}$ Sesudah hari ke 7 Pemberian Jus buah naga Pada lbu Hamil Di Puskesmas Liwa Lampung Barat Tahun 2019}

\begin{tabular}{lcccc}
\hline \multicolumn{1}{|l}{ Variabel } & $\mathrm{N}$ & Mean & Min-Mak & $\mathrm{SD}$ \\
\hline $\begin{array}{l}\text { Sesudah } \\
\text { hari ke } 7\end{array}$ & & & & \\
$\begin{array}{l}\text { pemberian } \\
\text { Jus buah }\end{array}$ & 18 & 10.928 & $10,0-12.4$ & 0.7169 \\
naga & & & & \\
\hline
\end{tabular}

Berdasarkan tabel. 2 Hasil analisis dapat dilihat dari 18 responden, diketahui bahwa setelah hari ke 7 pemberian Jus buah naga terhadap kenaikan kadar hemoglobin pada ibu hamil nilai minimal (nilai kadar hemoglobin terendah) 10,0 dan nilai maksimal (nilai kadar hemoglobin tertinggi) 
12.4 dengan nilai rata-rata sesudah pemberian Jus buah naga 10.928 dan standar deviasi 0.7169 .

Berdasarkan tabel. 3 Hasil analisis dapat dilihat dari 18 responden, diketahui bahwa pada hari ke 15 pemberian Jus buah naga terhadap kenaikan kadar hemoglobin pada ibu hamil nilai minimal (nilai kadar hemoglobin terendah) 10,4 dan nilai maksimal (nilai kadar hemoglobin tertinggi) 12.8 dengan nilai rata-rata sesudah pemberian jus buah naga 11.583 dan standar deviasi 0.6888 .
Tabel 3.

Distribusi frekuensi rata-rata kadar $\mathrm{Hb}$ Sesudah hari ke14 Pemberian Jus buah naga Pada lbu Hamil Di Puskesmas Liwa Lampung Barat Tahun 2019

\begin{tabular}{lcccc}
\hline \multicolumn{1}{c}{ Variabel } & $\mathrm{N}$ & Mean & Min-Mak & $\mathrm{SD}$ \\
\hline $\begin{array}{l}\text { Sesudah } \\
\text { hari ke15 }\end{array}$ & & & & \\
$\begin{array}{l}\text { pemberian } \\
\text { Jus buah } \\
\text { naga }\end{array}$ & 18 & 11.583 & $10,4-12.8$ & 0.6888 \\
\hline
\end{tabular}

\section{Analisis Bivariat}

Tabel 4.

Pengaruh pemberian Jus buah naga terhadap kadar hemoglobin Pada Ibu Hamil Di Puskesmas Liwa Lampung Barat Tahun 2019

\begin{tabular}{|c|c|c|c|c|c|c|}
\hline Variabel & $\begin{array}{l}\text { Mean (Nilai } \\
\text { Rata-Rata) }\end{array}$ & $\begin{array}{c}\text { SD } \\
\text { (Standar } \\
\text { Deviasi) } \\
\end{array}$ & P (Value) & $\mathrm{T}$ & $\begin{array}{l}\text { N (Jumlah } \\
\text { Sampel) }\end{array}$ & $\begin{array}{l}\text { Cl 95\% } \\
\text { (low-up) }\end{array}$ \\
\hline $\begin{array}{l}\text { Sebelum pemberian Jus } \\
\text { buah naga }\end{array}$ & 9.761 & 0.5304 & \multirow{2}{*}{0,000} & \multirow[b]{2}{*}{9,520} & \multirow{2}{*}{18} & \multirow{2}{*}{$\begin{array}{l}(1.6183- \\
0.7151)\end{array}$} \\
\hline $\begin{array}{l}\text { Sesudah pemberian Jus } \\
\text { buah naga }\end{array}$ & 11.583 & 0.6888 & & & & \\
\hline
\end{tabular}

Berdasarkan tabel 4. diatas, dapat dilihat nilai rata-rata, standar deviasi dan standar error untuk masing-masing variabel. Nilai rata-rata kadar hemoglobin sebelum pemberian Jus buah naga adalah 9.761, sedangkan nilai rata-rata kadar hemoglobin sesudah pemberian Jus buah naga adalah 11.583. Hasil uji statistik yang dilihat dari nilai Sig. (2-tailed) pada tabel dependent sample test adalah $0,000<0,05$, maka Ho ditolak. Dapat disimpulkan bahwa ada Pengaruh Pemberian Jus buah naga Terhadap Peningkatan Kadar Hb Pada lbu Hamil .

\section{PEMBAHASAN}

\section{Univariat}

Kadar Hemoglobin Sebelum Pemberian Jus buah naga

Berdasarkan tabel. 1 Hasil analisis dapat dilihat dari 18 responden, diketahui bahwa pemberian Jus buah naga terhadap kenaikan kadar hemoglobin pada ibu hamil nilai minimal (nilai kadar hemoglobin terendah) 9.0 dan nilai maksimal (nilai kadar hemoglobin tertinggi) 10,5 dengan nilai ratarata sebelum pemberian Jus buah naga 9.761 dan standar deviasi 0.5304 .

Menurut hasil penelitian Wulandari (2020) dengan judul jurnal review "Honey To Prevent Iron Deficiency Anemia In Pregnancy" disimpulkan bahwa Anemia gizi merupakan anemia terbanyak pada ibu hamil. Anemia gizi paling sering berupa defisiensi besi. Besi berfungsi untuk membentuk hemoglobin darah. Hemoglobin berfungsi untuk mengangkut oksigen (O2) dalam darah. Oleh karena itu, pada anemia gizi defisiensi besi diperlukan zat yang dapat membentuk hemoglobin agar jaringan tubuh mendapat $\mathrm{O} 2$ yang adekuat. Madu mengandung vitamin $\mathrm{C}$, vitamin $\mathrm{A}$, besi $(\mathrm{Fe})$, dan vitamin $\mathrm{B} 12$ yang berfungsi sebagai pembentukan sel darah merah dan hemoglobin. Sehingga dapat disimpulkan bahwa mengkonsumsi madu dapat mencegah anemia defisiensi besi pada ibu hamil.

Anemia defisiensi pada wanita hamil merupakan problema kesehatan yang dialami oleh wanita diseluruh dunia terutama dinegara perkembangan (Indonesia). WHO melaporkan bhawa prevalensi wanita hamil yang mengalami defisiensi sekitar $35-75 \%$ serta semakin meningkat seiring dengan bertambah usia. (Yeyeh, 2010)

Menurut peneliti peristiwa kehamilan dapat diterima dalam dua bentuk popok yaitu kehamilan yang diharapkan dan diterima dengan baik atau perasaan takut hamil dan menghadapi persalinan. Keluhan tersebut dapat menimbulkan berbagai bentuk gejala klinis sehingga memerlukan anjuran untuk dapat mengatasinya dan mulai beradaptasi 
terhadap kehamilan. Nasihat untuk ibu hamil mencakup anjuran yang berkaitan dengan pencegahan psikologis dan rasa takut menghadapi kehamilan dan persalinan.

Kadar hemoglobin setelah 14 hari pemberian Jus buah naga

Berdasarkan tabel. 3 Hasil analisis dapat dilihat dari 18 responden, diketahui bahwa hari ke 15 pemberian Jus buah naga terhadap kenaikan kadar hemoglobin pada ibu hamil nilai minimal (nilai kadar hemoglobin terendah) 10,4 dan nilai maksimal (nilai kadar hemoglobin tertinggi) 12.8 dengan nilai rata-rata sesudah pemberian jus buah naga 11.583 dan standar deviasi 0.6888 .

Menurut hasil penelitian Wulandari (2020) dengan judul jurnal review "Honey To Prevent Iron Deficiency Anemia In Pregnancy" disimpulkan bahwa Anemia gizi merupakan anemia terbanyak pada ibu hamil. Anemia gizi paling sering berupa defisiensi besi. Besi berfungsi untuk membentuk hemoglobin darah. Hemoglobin berfungsi untuk mengangkut oksigen (O2) dalam darah. Oleh karena itu, pada anemia gizi defisiensi besi diperlukan zat yang dapat membentuk hemoglobin agar jaringan tubuh mendapat $\mathrm{O} 2$ yang adekuat. Madu mengandung vitamin $\mathrm{C}$, vitamin $\mathrm{A}$, besi $(\mathrm{Fe})$, dan vitamin $\mathrm{B} 12$ yang berfungsi sebagai pembentukan sel darah merah dan hemoglobin. Sehingga dapat disimpulkan bahwa mengkonsumsi madu dapat mencegah anemia defisiensi besi pada ibu hamil.

Zat besi merupakan mikroelemen yang esensial bagi tubuh. Zat ini terutama diperlukan dalam hemopoboesis (pembentukan darah) yaitu sintesis hemoglobin $(\mathrm{Hb})$. Hemoglobin $(\mathrm{Hb})$ yaitu suatu oksigen yang mengantarkan eritrosit berfungsi penting bagi tubuh. Hemoglobin terdiri dari Fe (zat besi), protoporfirin, dan globin (1/3 berat $\mathrm{Hb}$ terdiri dari Fe). (Depkes RI, 2008).

Penambahan zat besi selama kehamilan kira-kira $1000 \mathrm{mg}$, karena mutlak dibutuhkan untuk janin, plasenta dan penambahan volume darah ibu. Sebagian dari peningkatan ini dapat dipenuhi oleh simpanan zat besi dan peningkatan adaptif persentase zat besi yang diserap. Tetapi bila simpanan zat besi rendah atau tidak ada sama sekali dan zat besi yang diserap dari makanan sangat sedikit maka, diperlukan suplemen preparat besi. (Depkes RI, 2007)

Berdasarkan hasil penelitian dimana hasil kadar hemoglobin pada ibu hamil tersebut berbedabeda hal tersebut dikarenakan oleh beberapa faktor seperti usia dan paritas ibu dimana ibu yang usianya lebih tua memiliki kadar hemoglobin lebih rendah dibanding ibu yang usianya lebih muda, dan ibu yang paritasnya lebih tinggi memiliki kadar hemoglobin yang lebih rendah dibandingkan ibu yang memiliki paritas primipara selain itu perbedaan kadar hemoglobin pada ibu hamil dikarenakan juga oleh seperti kebiasaan ibu hamil tersebut dalam memenuhi nutrisi ibu hamil yang didapatkan dari makanan yang mereka makan setiap harinya(Putri, S., \& Lathifah, N. S. (2019)

Berdasarkan hasil penelitian peneliti berasumsi bahwa ibu hamil setelah mengkonsumsi Jus buah naga Terhadap Peningkatan Kadar $\mathrm{Hb}$ Pada Ibu Hamil kadar hemoglobin naik nilai ratarata kadar hemoglobin sebelum pemberian Jus buah naga adalah 9.761 sedangkan nilai rata-rata kadar hemoglobin sesudah pemberian Jus buah naga adalah 11.583. sehingga mengkonsumsi Jus buah naga dapat dijadikan sebagai alternatif untuk menaikkan kadar hemoglobin pada ibu hamil tanpa ada efek samping.

\section{Bivariat}

Pengaruh pemberian Jus buah naga terhadap kadar hemoglobin Pada Ibu Hamil anemia

Berdasarkan tabel 4. diatas, dapat dilihat nilai rata-rata, standar deviasi dan standar error untuk masing-masing variabel. Nilai rata-rata kadar hemoglobin sebelum pemberian Jus buah naga adalah 9.761, sedangkan nilai rata-rata kadar hemoglobin sesudah pemberian Jus buah naga adalah 11.583. Hasil uji statistik yang dilihat dari nilai Sig. (2-tailed) pada tabel dependent sample test adalah $0,000<0,05$, maka Ho ditolak. Dapat disimpulkan bahwa ada Pengaruh Pemberian Jus buah naga Terhadap Peningkatan Kadar Hb Pada Ibu Hamil.

Menurut penelitian yang dilakukan widyaningsih (2017) ini mengungkapkan hal itu ada pengaruh yang signifikan secara statistik jus buah naga merah tingkat $\mathrm{Hb}$ pada Intervensi hari ke 7 dengan $p$-value $0,037(<0,05)$, tetapi tidak ada efek yang signifikan pada tingkat hemoglobin pada hari ke -14 intervensi dengan $p$-value 0,140 $(>0,05)$. Penelitian ini juga mengungkapkan bahwa ada pengaruh signifikan secara statistik merah jus buah naga pada wanita hamil tingkat eritrosit pada hari ke 7 dengan $p$ nilai $0,025(<0,05)$, tetapi tidak ada efek signifikan pada tingkat eritrosit pada hari ke 14 intervensi dengan p-nilai 0,094 (> 0,05).

Anemia dalam kehamilan didefinisikan sebagai penurunan kadar hemoglobin kurang dari $11 \mathrm{~g} / \mathrm{dl}$ selama masa kehamilan pada trimester I dan III dan kurang dari $10 \mathrm{~g} / \mathrm{dl}$ selama masa post partum dan trimester II. Darah akan bertambah 
banyak dalam kehamilan yang lazim disebut hidremia atau hipervolemia. Akan tetapi, bertambahnya sel darah kurang dibandingkan dengan bertambahnya plasma sehingga terjadi pengenceran darah. Perbadingannya tersebut adalah sebagai berikut: plasma $30 \%$, sel darah $18 \%$, dan hemoglobin 19\%. Bertambahnya darah dalam kehamilan sudah dimulai sejak kelahiran 10 minggu dan mencapai puncaknya dalam kehamilan antara 32 dan 36 minggu (Proverawati, 2009).

Pada saat hamil ibu harus makan makanan yang mengandung nilai gizi bermutu tinggi meskipun tidak berarti makanan yang mahal harganya. Gizi pada waktu hamil harus ditingkatkan hingga 300 kalori perhari, ibu hamil seharusnya mengkonsumsi makanan yang mengandung protein, zat besi, dan minum cukup cairan (menu seimbang).

Gizi sangat diperlukan untuk kesehatan ibu, kualitas kehamilan dan keselamatan bayi. Kebutuhan ibu selama kehamilan ialah $800 \mathrm{mg}$ besi, diantaranya $300 \mathrm{mg}$ untuk janin plasenta dan $500 \mathrm{mg}$ untuk pertambahan eritrosit ibu. Dengan demikian ibu membutuhkan tambahan sekitar 2-3 $\mathrm{mg}$ besi/ hari. Ibu Hamil memerlukan banyak makanan tambahan diantaranya yaitu protein, vitamin $\mathrm{C}$ dan zat-zat besi dibanding wanita biasa. Apabila ibu hamil sampai kekurangan gizi terutama zat besi dan asam folat maka dapat terjadi anemia defisiensi besi karena dalam kehamilan keperluan zat-zat makanan bertambah dan terjadi pula perubahan-perubahan dalam darah dan sum-sum tulang. Selain itu kebutuhan zat gizi selama hamil diperlukan untuk pertumbuhan janin, plasenta dan jaringan lainnya (Muhilal, 2002).

Nutrisi yang baik adalah cara terbaik untuk mencegah terjadinya anemia jika sedang hamil atau mencoba menjadi hamil. Makan makanan yang tinggi kandungan zat besi (seperti sayuran berdaun hijau, daging merah, sereal, telur, dan kacang tanah) dapat membantu memastikan bahwa tubuh menjaga pasokan besi yang diperlukan untuk berfungsi dengan baik. Pemberian vitamin untuk memastikan bahwa tubuh memiliki cukup asam besi dan folat. Pastikan tubuh mendapatkan setidaknya $27 \mathrm{mg}$ zat besi setiap hari. Jika mengalami anemia selama kehamilan, biasanya dapat diobati dengan mengambil suplemen zat besi. Pastikan bahwa wanita hamil dicek pada kunjungan pertama kehamilan untuk pemeriksaan anemia. (Proverawati, 2011).

Dalam 100 gram buah naga mengandung nilai gizi $11,5 \mathrm{~g}$ karbohidrat, $0,15-0,22 \mathrm{~g}$ protein, 0,21-0,61 g lemak, 13- 180 briks kadar gula, 0,20,9 g serat, 0,005-0,01 g karoten, 6,3-8,8 mg kalsium, 30,2-31,6 mg fosfor, 0,55-0,65 mg besi, 60,4 mg magnesium, vitamin B1, B2, C dan 82,5-83 $\mathrm{g}$ air (Cahyono 2009 dalam Rizal, 2015). Kadar air buah naga tergolong tinggi $90 \%$ sehingga tidak dapat disimpan lama yaitu hanya 7-10 hari pada suhu 140 C (Farika, dkk, 2013). Sedangkan dalam 100 gram buah naga mengandung $0,16 \mathrm{mg}$ zat besi, kebutuhan zat besi untuk ibu hamil perhari sebesar 0,8 mg. Zat besi ini akan diubah menjadi darah merah Sel-sel, sehingga bermanfaat untuk hamil wanita yang cenderung mengalami anemia. Seperti literatur juga mengatakan bahwa buah naga mengandung zat besi dan vitamin dalam jumlah tinggi $\mathrm{C}$ yang membantu meningkatkan jumlah hemoglobin Anda secara substansial selama kehamilan.

Proses pembentukan eritrosit disebut eritropoisis, dalam tubuh terdapat 3-5 atau 2,5-4 gram $\mathrm{Fe}, 30-40 \%$ nya dalam bentuk cadangan besi. Distribusi Fe 70\% (2- 2,5 g) terdapat dalam $\mathrm{Hb}$. $26 \%$ sebagai cadangan besi dalam liver, limpa dan tulang. Dalam makanan, besi sebagai ikatan organik yaitu garam Fe (Ferro dan Ferri sulfat). Bentuk ferro lebih mudah diserap. Di dalam tubuh Fe berikatan dengan protein (bentuk ferro maupun ferri). Bentuk aktif umumnya berupa bentuk ferro. Terdapat 2 bentuk besi yaitu Besi Heme dan non heme, pada daging merah terdapat $40 \%$ besi heme dan $60 \%$ besi non heme. Banyak berasal dari hemoglobin dan myoglobin dalam daging, unggas dan ikan. Hanya terdapat 5-10\% dari makanan yang dikonsumsi. Penyerapan 2-3x lebih mudah, relative tidak banyak dipengaruhi oleh factor lain dalam makanan. Kebanyakan besi yang ada di makanan adalah besi non heme. Besi non heme ini biasanya didapati pada sayuran dan buah-buahan. Sekitar $25-35 \%$ besi heme yang diabsorbsi, sedangkan pada besi non heme mengalami penurunan $3 \%$ dari besi heme untuk penyerapannya. Perbedaan jumlah yang diabsorbsi ini sangat penting. Besi heme hanya ada pada daging hewan. Sehingga bagi vegetarian harus waspada akan jumlah besi non heme yang hanya sedikit diabsorbsi.

Berdasarkan hasil penelitian yang dilakukan pengukuran sebelum pemberian, hari ke 7 dan hari ke 15 dikarenakan untuk mengetahui naik turunya kadar hemoglobin sesudah pemberian jus buah naga serta sebagai bahan evaluasi dalam penanganan ibu hamil dengan kadar hemoglobin dibawah normal, perbedaan kenaikan kadar hemoglobin pada ibu hamil sebelum dan sesudah mengkonsumsi jus buah naga disebabkan karena asupan nutrisi yang tidak cukup, bertambahnya zat gizi yang hilang, dan meningkatnya kebutuhan nutrisi ibu selama masa hamil. 


\section{KESIMPULAN}

Dari hasil penelitian dan pembahasan pada bab sebelumnya, maka dapat disimpulkan hal-hal sebagai berikut:

Nilai rata-rata kadar hemoglobin sebelum pemberian Jus buah naga 9.761 dan standar deviasi 0.5304.Nilai rata-rata kadar hemoglobin setelah 14 hari setelah pemberian Jus buah naga 11.583 dan standar deviasi 0.6888. Ada Pengaruh Pemberian Jus buah naga Terhadap Peningkatan Kadar Hb Pada Ibu Hamil ( $p$ value $0,000<0,05$ ).

\section{SARAN}

Bagi Ibu Hamil, Ibu hamil diharapkan melakukan pemeriksaan ANC sejak kehamilan awal sehingga akan diketahui status anemia sejak TM I dan mengkonsumsi jus buah naga yang dibarengi dengan FE serta konseling gizi. Upaya untuk meningkatkan status gizi ibu hamil perlu mengkonsumsi nutrisi yang baik, konsumsi tablet ferum secara rutin, mengurangi aktivitas yang berlebih, meningkatkan pengetahuan tentang kebutuhan gizi dan nutrisi selama kehamilan. Bagi petugas kesehatan, bidan dan petugas gizi di Puskesmas diharapkan meningkatkan intensitas edukasi atau konseling gizi tidak hanya pada ibu hamil yang anemia saja tetapi pada seluruh ibu hamil. Pemberian edukasi atau konseling gizi diharapkan dilakukan sejak ibu terdeteksi hamil atau pada TM I sehingga pemenuhan kebutuhan gizi terutama asupan zat besi tidak hanya didapatkan dari suplementasi TTD. Hal ini dapat dijadikan sebagai pedoman dalam upaya mengurangi risiko anemia pada ibu hamil.Bagi Tempat Penelitian, penelitian ini dapat dijadikan sebagai metode nonfarmakologi untuk tindakan menaikkan kadar hemoglobin salah satunya dengan Pemberian Jus buah naga Terhadap Peningkatan Kadar $\mathrm{Hb}$ Pada Ibu Hamil serta melakukan penyuluhan-penyuluhan untuk menambah pengetahuan hamil tentang penanganan anemia. Bagi Peneliti Selanjutnya, penelitian ini dapat diteliti lebih dalam dan lebih jauh lagi tentang minat ibu hamil terhadap buah naga dengan menggunakan analisis yang berbeda dan metode yang berbeda sehingga memperkaya analisis data penelitian.

\section{DAFTAR PUSTAKA}

Walyani, E. S. (2015). Asuhan kebidanan pada kehamilan. Yogyakarta: Pustaka.

Siti, F. (2016). Gizi dan Kesehatan Untuk Ibu Hamil Hastono, S. P. (2007). Analisa data kesehatan. Jakarta: Universitas Indonesia.

Istiyati, S., \& Satriyandari, Y. (2019). Hubungan Anemia pada ibu hammil dengan kejadian BBLR di RS PKU MUHAMMADIYAH Yogyakarta

Jannah Nurul, 2012. Asuhan Kebidanan : Kehamilan. Yogyakarta. Andi Offse

Kemenkes, R. I. (2016). Pedoman Pencegahan dan Penanggulangan Anemia Pada Remaja Putri dan Wanita Usia Subur (WUS). Direktorat Gizi Masyarakat Direktorat Jenderal Kesehatan Masyarakat Kementerian Kesehatan RI.

Kementerian Kesehatan RI, 2013.Prevalensi Anemia Pada Ibu Hamil

Luh Seri, 2018. Buku saku anemia defisiensi besi masa prahamil \& hamil. Jakarta: EGC

Notoatmodjo, S. (2012). Metodologi penelitian kesehatan (Cetakan VI). Jakarta: Penerbit PT. Rineka Cipta.

Proverawati, A. (2011). Anemia dan Anemia kehamilan. Yogyakarta: Nuha Medika, 136137.

Putri, S., \& Lathifah, N. S. (2019). Perbedaan Pemberian Tablet Fe dengan Jus jeruk dan tablet $\mathrm{Fe}$ dengan vitamin $\mathrm{C}$ terhadap kenaikan kadar hemoglobin pada ibu hamil trimester II. Jurnal Kebidanan Malahayati, $5(2)$.

Romauli, S. (2011). Konsep Dasar Asuhan Kehamilan. Yogyakarta: Nuha Medika.

Margareth, Z. H., \& Sukarni, I. K. (2013). Kehamilan, persalinan, dan nifas. Yogyakarta: Nuha Medika.

Sulistyawati, A. (2011). Salemba Medika: Asuhan Kebidanan Pada Masa Kehamilan.

Winarsih, 2018. Pengantar ilmu gizi dalam kebidanan. Yogyakarta: Pustakabarupress 